\title{
Model Rantai Markov dan Model ARIMA serta Kombinasinya dalam Memprediksi Curah Hujan di Kota Makassar
}

\author{
Ahmad Zaki ${ }^{1}$, Wahidah Sanusi ${ }^{1}$, Saiful Bahri ${ }^{1, a)}$ \\ ${ }^{1)}$ Jurusan Matematika, Fakultas Matematika dan Ilmu Pengetahuan Alam, Universitas Negeri \\ Makassar, 90224 \\ a) mailbox.saiful@gmail.com
}

\begin{abstract}
Abstrak. Curah hujan merupakan suatu data deret waktu yang bersifat kontinu, namun juga dapat diformulasikan sebagai peubah diskrit yaitu dengan menggolongkan suatu hari menjadi hujan dan tidak hujan. Curah hujan yang dicatat oleh pos hujan dapat digunakan untuk memprediksi curah hujan pada waktu yang akan datang melalui pemodelan deret waktu ARIMA musiman, Rantai Markov atau dengan campuran keduanya. Proses Markov merupakan suatu sistem stokastik di mana kejadian di masa yang akan datang bergantung pada kejadian sesaat sebelumnya Deret waktu merupakan serangkaian data yang disusun menurut urutan waktu Tujuan penelitian ini adalah untuk memodelkan dan memprediksi curah hujan dengan campuran Rantai Markov dan model deret waktu. Data yang digunakan dalam penelitian ini adalah curah hujan bulanan kota Makassar tahun 2007 sampai 2017. Campuran model deret waktu lebih sesuai digunakan untuk memprediksi curah hujan bulanan dibandingkan dengan pemodelan deret waktu saja hal ini dapat dilihat dai nilai MSE.
\end{abstract}

Kata Kunci: Rantai Markov, Deret Waktu, ARIMA Musiman

\begin{abstract}
Rainfall is a time series data that is continuous, but can also be formulated as a discrete variable that is by classifying one day as rainy and not rainy. Rainfall recorded by rain posts can be used to predict rainfall in the future through seasonal ARIMA time series modeling, Markov Chain or with a mixture of both. The Markov process is a stochastic system in which future events depend on the events of the previous moment. The time series is a series of data arranged in time sequence. The purpose of this study is to model and predict rainfall with a mixture of Markov Chains and time series models. The data used in this study is the monthly rainfall of Makassar city in 2007 to 2017. A mixture of time series models is more suitable to be used to predict monthly rainfall compared to modeling time series. This can be seen from the MSE value. Keywords: Markov chain, Time Series, seasonal ARIMA.
\end{abstract}

\section{PENDAHULUAN}

Curah hujan di Indonesia setiap tahunnya rata-rata tidak selalu sama. Variabilitas curah hujan yang besar bergantung dalam ruang dan waktu. Namun belakangan terjadi perubahan fisik atmosfir dari variabilitas komponen cuaca normal menuju kondisi ekstrim dalam kurun waktu yang panjang dan membawa dampak luas terhadap berbagai sektor kehidupan manusia.

Secara umum Kota Makassar mengalami musim hujan pada bulan November-April dan musim kemarau pada bulan Mei-Oktober. Curah hujan rata-rata tahunan sekitar $256.08 \mathrm{~mm} / \mathrm{bulan}$ (Badan Pusat Statistika Kota Makassar). Namun, terkait dengan perubahan iklim di Sulawesi-Selatan, bulan Agustus-September biasanya masih merupakan musim kemarau, namun kali ini masuk 
kategori musim kemarau basah sehingga hujan di beberapa wilayah di Kota Makassar kerap terjadi.

Hidrologi merupakan ilmu yang berkaitan dengan air di bumi, salah satunya tentang curah hujan. Pengukuran curah hujan dilakukan setiap hari dan hasilnya dapat digunakan sebagai informasi hidrologi, misalnya untuk memprediksi curah hujan yang akan datang. Curah hujan yang dicatat merupakan suatu data deret waktu yang bersifat kontinu, namun juga dapat diformulasikan sebagai peubah diskrit. Oleh karena itu, prediksi curah hujan dapat dilakukan melalui pemodelan deret waktu maupun dengan rantai Markov.

Proses Markov merupakan suatu sistem stokastik di mana kejadian di masa yang akan datang

bergantung pada kejadian sesaat sebelumnya. Pemodelan curah hujan dengan rantai Markov sudah pernah dilakukan oleh Gunawan (2007) yaitu membandingkan metode rantai Markov dan regresi logistik untuk memprediksi hari hujan dan tidak hujan di Kota Malang, namun belum dapat memprediksi curah hujan.

Model deret waktu merupakan salah satu bagian dari ilmu matematika yang paling banyak dipelajari oleh para ilmuan, khususnya para peneliti, baik ilmuan bidang sosial maupun eksakta. Model ARIMA (autoregresif integrated moving average) merupakan salah satu model deret waktu yang berbentuk system simultan. (Pratiwi., 2012). Pemodelan Curah hujan dengan metode ARIMA pernah dilakukan oleh Pratiwi (2012), yaitu dengan membandingkan metode jaringan syaraf tiruan backpropagation dengan metode box-jenkins (ARIMA) dalam meramalkan curah hujan.

Penelitian ini akan mengembangkan rantai Markov dan metode ARIMA serta kombinasinya untuk memprediksi curah hujan dengan satuan waktu bulanan. Dengan model campuran apabila diprediksi tidak terjadi hujan, maka curah hujan dalam bulan tersebut adalah nol atau tidak terjadi hujan samasekali.

\section{KAJIAN PUSTAKA}

Proses Markov digunakan untuk mengukur atau mengetimasi pergerakan yang terjadi setiap saat. Proses ini melibatkan penggunaan matriks transisi markov, dimana setiap nilai dalam matriks transisi adalah probabilitas pergerakan dari suatu keadaan ke keadaan lainnya (syafruddin ,Irma \& Sukarna, 2014).

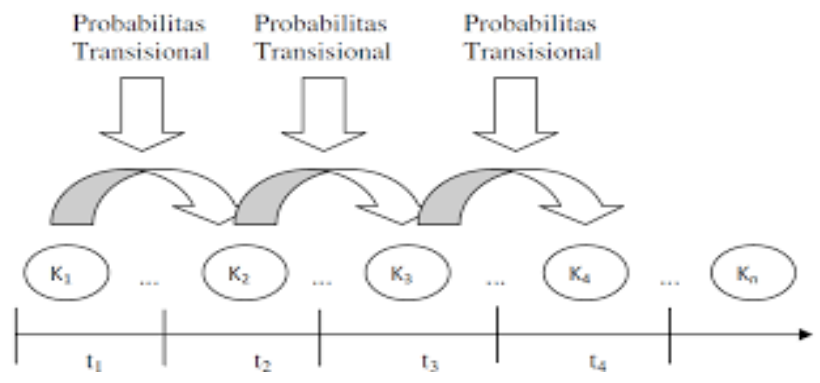

GAMBAR 1. Peristiwa Rantai Markov

Untuk setiap waktu t, ketika kejadian adalah $K_{t}$ dan seluruh kejadian sebelumnya adalah $K_{t(j) \text {, }}$ $\ldots, K_{t(j-n)}$ yang terjadi dari proses yamg diketahui, probabilitas seluruh kejadian yang datang $K_{t(j)}$ hanya bergantung pada kejadian $K_{t(j-1)}$ dan tidak be rgantung pada kejadian-kejadian sebelumnya yaitu $K_{t(j-1)}, K_{t(j-2)}, \ldots, K_{t(j-n)}$ (Syafruddin ,dkk, 2014).

Probabilitas menunjukkan kemungkinan terjadinya suatu peristiwa yang bersifat acak. Suatu peristiwa disebut acak jika terjadi peristiwa tersebut tidak diketahui sebelumnya. Oleh karena itu probabilitas dapat digunakan sebagai alat ukur terjadinya peristiwa dimasa yang akan datang. 
Jika $S$ mempunyai $n$ anggota dan $A$ sebuah peristiwa yang diturunkan dari $S$, maka :

$$
P(A)=\frac{n(A)}{n(S)}
$$

Dimana $\quad: P(A)$ adalah probabilitas terjadinya peristiwa $\mathrm{A}, n(A)$ adalah banyaknya peristiwa A dan $n(S)$ adalah banyaknya peristiwa $S$ (Syafruddin ,Irma \& Sukarna., 2014).

Deret waktu merupakan serangkaian data pengamatan yang terjadi berdasarkan indeks waktu secara berurutan dengan interval waktu tetap. Analisis deret waktu adalah salah satu prosedur statistika yang diterapkan untuk meramalkan struktur probabilitastik keadaan yang akan terjadi di masa yang akan datang dalan rangka pengambilan keputusan (Aswi \& Sukarna, 2006).

Menurut Anugerah (2007) Tahapan dalam metode ARIMA yaitu :

1. Tahap identifikasi

2. Tahap penaksiran parameter

3. Tahap pemeriksaan diagnostik.

4. Peramalan dengan model yang paling sesuai.

Pada model kombinasi Hasil prediksi Rantai Markov Berupa bulan hujan (1) dan bulan tidak hujan (0). Hasil dari model camputran didapat dengan mengalikan hasil prediksi Rantai Markov berupa bulan hujan dan tidak hujan dalam bentuk 0 dan 1(Pratiwi, 2012)

\section{METODE PENELITIAN}

Penelitian ini merupakan penelitian terapan yang bertujuan untuk meramalkan curah hujan dengan menggunakan metode ARIMA dan Metode Rantai Markov serta kombinasi dari kedua metode tersebut. Data yang digunakan yaitu data curah hujan bulanan di Kota Makassar yang diambil dari website Badan Meteorologi, Klimatologi dan Geofisika (BMKG) Kota Makassar Sulawesi Selatan, dari Bulan Januari 2007 sampai Desember 2017 di Stasiun Meteorologi Maritim Paotere. Data tersebut dianalisis dengan menggunakan program komputer berupa software MINITAB 16 dan Microsoft Excel.

\section{HASIL DAN PEMBAHASAN}

Prediksi dengan menggunakan Rantai Markov

Untuk menentukan matriks peluang transisi digunakan Tabel 1

TABEL 1. Perubahan keadaan

\begin{tabular}{cccc}
\hline Keadaan Bulan & Bulan Hujan & Bulan Tidak Hujan & Jumlah \\
\hline Bulan hujan & 8 & 9 & $\mathbf{1 7}$ \\
Bulan Tidak hujan & 94 & 9 & $\mathbf{1 0 2}$ \\
\hline
\end{tabular}

Dengan menggunakan persamaan (1) akan diperoleh :

$P_{11}=\frac{n(1)}{n(s)}=\frac{8}{17}=0,471$
$P_{12}=\frac{n(2)}{n(s)}=\frac{9}{17}=0,529$ 
$P_{21}=\frac{n(1)}{n(s)}=\frac{94}{102}=0,922$

$P_{22}=\frac{n(2)}{n(s)}=\frac{8}{102}=0,078$

Dari nilai P yang dihasilkan dari tabel perubahan dapat ditentukan nilai dari matriks probabilitas transisi yang juga merupakan model rantai markov yang dihasilkan.

$$
P=\left[\begin{array}{ll}
0,471 & 0,529 \\
0,922 & 0,078
\end{array}\right]
$$

Prediksi bulan hujan dan tidak hujan dilakukan berdasarkan pengamatan pada bulan sebelumnya dan matriks peluang transisi. Apabila keadaan bulan sebelumnya hujan maka bentuk matriksnya yaitu : [1 0 0], dan apabila bulan tersebut tidak hujan maka bentuk matriksnya yaitu : $\left[\begin{array}{ll}0 & 1\end{array}\right]$.

Karena pada bulan sebelumnya merupakan bulan tidak hujan yaitu pada bulan Desember 2016 maka digunakan matriks [0 1 1] untuk memprediksi apakah bulan setelahnya hujan atau tidak hujan dengan cara mengalikannya dengan matriks probabilitas transisi $(\boldsymbol{P})$. Berikut hasil prediksi curah hujan bulanan Kota Makassar Tahun 2017 dengan menggonakan metode markov

$$
\begin{aligned}
& \text { Bulan Januari }=\left[\begin{array}{ll}
0 & 1
\end{array}\right] X\left[\begin{array}{ll}
0,471 & 0,529 \\
0,922 & 0,078
\end{array}\right]=\left[\begin{array}{ll}
0,471 & 0,529
\end{array}\right] \\
& \text { Bulan Februari }=\left[\begin{array}{ll}
0,471 & 0,529
\end{array}\right] X\left[\begin{array}{ll}
0,471 & 0,529 \\
0,922 & 0,078
\end{array}\right]=\left[\begin{array}{ll}
0,710 & 0,290
\end{array}\right] \\
& \text { Bulan Maret }=\left[\begin{array}{ll}
0,710 & 0,290
\end{array}\right] X\left[\begin{array}{ll}
0,471 & 0,529 \\
0,922 & 0,078
\end{array}\right]=\left[\begin{array}{ll}
0,602 & 0,398
\end{array}\right] \\
& \text { Bulan Apil } \quad=\left[\begin{array}{ll}
0,602 & 0,398
\end{array}\right] X\left[\begin{array}{ll}
0,471 & 0,529 \\
0,922 & 0,078
\end{array}\right]=\left[\begin{array}{ll}
0,651 & 0,349
\end{array}\right] \\
& \text { Bulan Mei } \quad=\left[\begin{array}{ll}
0,651 & 0,349
\end{array}\right] X\left[\begin{array}{ll}
0,471 & 0,529 \\
0,922 & 0,078
\end{array}\right]=\left[\begin{array}{ll}
0,629 & 0,371
\end{array}\right] \\
& \text { Bulan Juni } \quad=\left[\begin{array}{ll}
0,629 & 0,371
\end{array}\right] X\left[\begin{array}{ll}
0,471 & 0,529 \\
0,922 & 0,078
\end{array}\right]=\left[\begin{array}{ll}
0,638 & 0,362
\end{array}\right] \\
& \text { Bulan Juli } \quad=\left[\begin{array}{ll}
0,638 & 0,362
\end{array}\right] X\left[\begin{array}{ll}
0,471 & 0,529 \\
0,922 & 0,078
\end{array}\right]=\left[\begin{array}{ll}
0,634 & 0,366
\end{array}\right] \\
& \text { Bulan Agustus }=\left[\begin{array}{ll}
0,634 & 0,366
\end{array}\right] X\left[\begin{array}{ll}
0,471 & 0,529 \\
0,922 & 0,078
\end{array}\right]=\left[\begin{array}{ll}
0,636 & 0,364
\end{array}\right] \\
& \text { Bulan September }=\left[\begin{array}{ll}
0,636 & 0,364
\end{array}\right] X\left[\begin{array}{ll}
0,471 & 0,529 \\
0,922 & 0,078
\end{array}\right]=\left[\begin{array}{ll}
0,635 & 0,365
\end{array}\right] \\
& \text { Bulan Oktober }=\left[\begin{array}{ll}
0,635 & 0,365
\end{array}\right] X\left[\begin{array}{ll}
0,471 & 0,529 \\
0,922 & 0,078
\end{array}\right]=\left[\begin{array}{ll}
0,636 & 0,364
\end{array}\right] \\
& \text { Bulan November }=\left[\begin{array}{ll}
0,636 & 0,364
\end{array}\right] X\left[\begin{array}{ll}
0,471 & 0,529 \\
0,922 & 0,078
\end{array}\right]=\left[\begin{array}{ll}
0,635 & 0,365
\end{array}\right] \\
& \text { Bulan Desember }=\left[\begin{array}{ll}
0,635 & 0,365
\end{array}\right] X\left[\begin{array}{ll}
0,471 & 0,529 \\
0,922 & 0,078
\end{array}\right]=\left[\begin{array}{ll}
0,635 & 0,365
\end{array}\right]
\end{aligned}
$$

Hasil prediksi Hasil Prediksi Rantai Markov Pada tahun 2017, dinyatakan pada Tabel 2 : 
TABEL 2. Hasil Prediksi Rantai Markov Pada tahun 2017

\begin{tabular}{cc}
\hline Bulan & Hasil Prediksi \\
\hline Januari & Tidak Hujan (0) \\
Februari & Hujan (1) \\
Maret & Hujan (1) \\
April & Hujan (1) \\
Mei & Hujan (1) \\
Juni & Hujan (1) \\
Juli & Hujan (1) \\
Agustus & Hujan (1) \\
September & Hujan (1) \\
Oktober & Hujan (1) \\
November & Hujan (1) \\
Desember & Hujan (1) \\
\hline
\end{tabular}

\section{Prediksi dengan Model Deret Waktu}

Prediksi dengan model deret waktu menggunakan program komputer berupa software MINITAB 16, dan di dapatkan estimasi model dinyatakan pada Gambar 2.

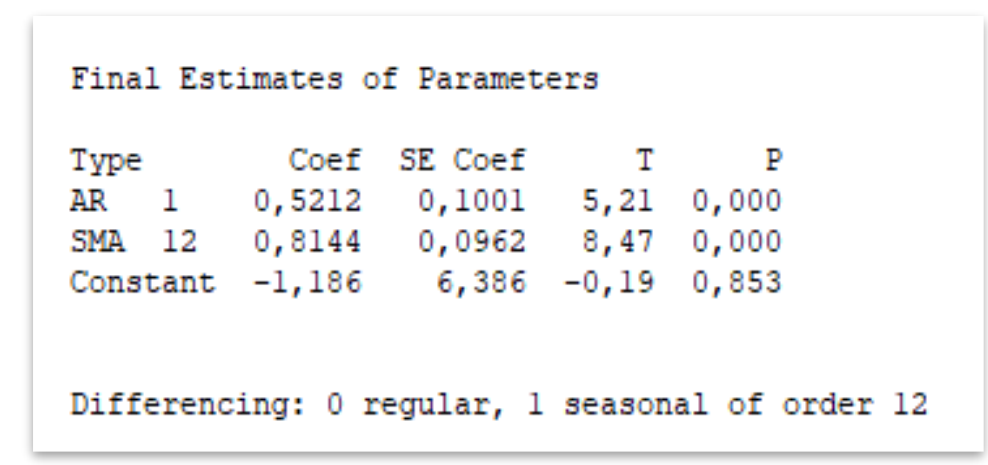

GAMBAR 2. Hasil estimasi model

Pada tahap penaksiran model dengan mengamati plot ACF dan PACF terdapat tiga model yang sementara yang dihasilka sebelum ke tahap identifikasi model yaitu, ARIMA $(1,0,0)(1,1,0)^{12}$, ARIMA $(1,0,0)(0,1,1)^{12}$, dan ARIMA $(1,0,0)(1,1,1)^{12}$

Dari ketiga model hasil identifikasi setelah dilakukan pemeriksaan model dengan menggunakan bantuan program minitab, model yang sesuai untuk digunakan adalah model ARIMA $(1,0,0)$ $(0,1,1)^{12}$, karena nilai P baik AR ataupun MA lebih kecil dari nilai $\alpha=0,05$

Dari proses pemeriksaan diagnostic diperoleh bahwa model ARIMA $(1,0,0)(0,1,1)^{12}$ dapat digunakan untuk meramalkan curah hujan. Model tersebut digunakan untuk meramalkan curah hujan dari Januari 2017 - Desember 2017. Dan model ini juga akan dikombinasikan dengan Rantai Markov untuk membandingkan keefektifannya jika hanya menggunakan model ARIMA.

\section{Prediksi Model Gabungan Rantai Markov dan Model ARIMA}

Model gabungan Rantai Markov dan Model Arima yaitu dengan mengalikan hasil dari prediksi rantai markov dengna hasil prediksi dari ARIMA dinyatakan pada Tabel 3 
TABEL 3. Hasil Prediksi Rantai Markov, ARIMA dan nilai MSE

\begin{tabular}{ccccc}
\hline Bulan & $\begin{array}{c}\text { Curah Hujan } \\
\text { Bulanan tahun } \\
\mathbf{2 0 1 7}\end{array}$ & $\begin{array}{c}\text { Hasil Prediksi } \\
\text { Rantai Markov }\end{array}$ & $\begin{array}{c}\text { Hasil Prediksi } \\
\text { ARIMA }\end{array}$ & $\begin{array}{c}\text { Hasil Prediksi } \\
\text { Kombinasi } \\
\text { Rantai Markov } \\
\text { dan ARIMA }\end{array}$ \\
\hline Januari & 732 & 0 & 459,5 & 0 \\
Februari & 399,9 & 1 & 367,06 & 367,06 \\
Maret & 449 & 1 & 439,83 & 439,83 \\
April & 225 & 1 & 330,06 & 330,06 \\
Mei & 45 & 1 & 391,81 & 391.81 \\
Juni & 194,1 & 1 & 425,17 & 425,17 \\
Juli & 21,4 & 1 & 229,74 & 229,74 \\
Agustus & 51,9 & 1 & 191,16 & 191,16 \\
September & 68 & 1 & 126,95 & 126,95 \\
Oktober & 90,3 & 1 & 174.4 & 174,4 \\
November & 496 & 1 & 176,56 & 176,56 \\
Desember & 955,5 & 1 & 300,65 & 300,65 \\
\hline MSE (mean & & & 25,05416667 & 14,713333 \\
square error) & & & & \\
\hline
\end{tabular}

Berdasarkan hasil prediksi curah hujan dengan menggunakan Rantai Markov, ARIMA musiman serta gabungan dari keduanya di dapati bahwa informasi yang dihasilkan Rantai Markov tidak mutlak menjadi suatu keputusan, karena sifatnya yang hanya memberikan bantuan dalam proses pengambilan keputusan.

Dengan mengamati hasil dari prediksi ARIMA dan gabungan Rantai Markov dan ARIMA hasil MSE (mean square error) pada Tabel 3, terlihat bahwa nilai MSE dari ARIMA yaitu 25,0541 lebih besar daripada nilai MSE dari gabungan Rantai Markov dan ARIMA itu menunjukkan bahwa prediksi curah hujan dengan Metode ARIMA dan dibantu dengan metode Rantai Markov itu menghasilkan hasil ramalan yang lebih efektif jika hanya metode ARIMA saja yang digunakan.

\section{KESIMPULAN}

Informasi yang dihasilkan Rantai Markov tidak mutlak menjadi suatu keputusan, karena sifatnya yang hanya memberikan bantuan dalam proses pengambilan keputusan, sehingga metode Rantai Markov yang menghasilkan prediksi curah hujan berupa bulan hujan dan tidak hujan berfungsi untuk membantu model ARIMA dalam menghasilkan keputusan. Dari proses pemeriksaan diagnostic diperoleh bahwa model ARIMA musiman $(1,0,0)(0,1,1)^{12}$ dapat digunakan untuk meramalkan curah hujan.

Kombinasi campuran Rantai Markov dan model deret waktu ARIMA musiman lebih sesuai digunakan untuk memprediksi curah hujan bulanan. Hal ini didasarkan pada nilai MSE (Mean Square Error) model kombinasi yang lebih kecil jika dibandingkan dengan model deret waktu. Namun, nilai MSE kedua model tersebut relatif besar, sehingga perlu dilakukan penelitian lebih lanjut dengan model campuran lain yang dapat menggambarkan fenomena curah hujan dengan lebih baik. 


\section{DAFTAR PUSTAKA}

Aswi \& Sukarna. (2006). Analisis Deret Waktu. Makassar: Andira Publisher

Anugerah P. (2007). Perbandingan Jaringan Syaraf Tiruan Backpropagation Dan Metode Deret Berkala Box-Jenkins (Arima) Sebagai Metode Peramalan Curah Hujan (Skripsi, tidak dipublikasikan). Universitas Negeri Semarang, Semarang.

Gunawan M. (2007). Kajian Model Rantai Markov dan Regresi Logistik dalam Pemodelan Hari Hujan dan Tidak Hujan di Kota Malang (Skripsi, tidak dipublikasikan). Universitas Brawijaya, Malang.

Pratiwi R . (2012). Pemodelan Curah Hujan Dengan Rantai Markov (Skripsi, tidak dipublikasikan). Universitas Brawijaya, Malang.

Syafruddin S, Irma S, \& Sukarna. (2014). Aplikasi Analisis Rantai Markov untuk Memprediksi Status Pasien Rumah Sakit Daerah Kabupaten Barru. Online Jurnal of Natural Science, 3(3). 313-321 